\title{
the Microstructure, Tensile Properties, and Fractography of Cast Mg-Based Alloys
}

\author{
M. H. Abdelaziz, ${ }^{1}$ M. Paradis, ${ }^{1}$ A. M. Samuel, ${ }^{1}$ H. W. Doty, ${ }^{2}$ and F. H. Samuel ${ }^{1}$ \\ ${ }^{1}$ Département des Sciences Appliquées, Université du Québec à Chicoutimi, Chicoutimi, QC, Canada \\ ${ }^{2}$ Materials Engineering, General Motors, 823 Joslyn Avenue, Pontiac, MI 48340, USA \\ Correspondence should be addressed to F. H. Samuel; fhsamuel@uqac.ca
}

Received 14 March 2017; Revised 2 May 2017; Accepted 6 June 2017; Published 10 August 2017

Academic Editor: Antonino Squillace

Copyright ( $\odot 2017$ M. H. Abdelaziz et al. This is an open access article distributed under the Creative Commons Attribution License, which permits unrestricted use, distribution, and reproduction in any medium, provided the original work is properly cited.

The present study was performed on Mg-based alloys containing $\mathrm{Zn}$ and $\mathrm{Mn}$. The alloys were cast in a permanent metallic mold preheated to $200^{\circ} \mathrm{C}$ and with a protective atmosphere of dry air, $\mathrm{CO}_{2}$, and $\mathrm{SF}_{6}$. Two main phases are observed in the as-cast condition: $\mathrm{Mg}-\mathrm{Al}-\mathrm{Zn}$ and $\mathrm{Mn}-\mathrm{Al}$ intermetallics. The size and morphology of the $\mathrm{Mg}-\mathrm{Al}-\mathrm{Zn}$ phase are significantly affected by the concentration of Al. Tensile properties, using standard ASTM B-108 samples, are directly related to the size, morphology, and density of the existing phase particles. The alloy ductility is reduced with increase in the Al concentration, whereas the ultimate tensile strength and the yield strength are more or less stable. The fracture surface of the tested tensile bars is mostly ductile for low $\mathrm{Al}$-containing alloys and tends to be brittle with the increase in $\mathrm{Al}$ content as evidenced by an increase in the density of cleavage ruptured areas.

\section{Introduction}

Commercial Mg-based alloys normally contain $3-13 \%$ aluminum, $0.1-0.4 \% \mathrm{Mn}$, and $0.5-3 \% \mathrm{Zn}$. The $\mathrm{AZ}$ series (e.g., AZ63, AZ92, AZ31, and AZ61) is normally used in sand castings and die castings as well as extrusion. The M1 alloy (Mg alloy with $1 \% \mathrm{Mn}$ ) is applied for castings that require low strength or welding [1-5]. The influence of additives in commercially available magnesium alloys (AZ31, AM50) on their microstructure and mechanical properties has been investigated [6-8].

Yamashita et al. [9] studied the mechanical properties of magnesium and its alloys subjected to heavy plastic deformation. Pure Mg and Mg alloys have limited ductility at ambient temperature. Magnesium alloys may be considered for aeronautical applications due their high mechanical properties provided by a fine-grained structure [10]. High strength coupled with high ductility at room temperature is achieved by grain refinement. Furthermore, fine-grained magnesiumbased materials exhibit superplastic behavior at high strain rates $\left(\geq 10^{-1} \mathrm{~s}^{-1}\right)$ or low temperatures $(\leq 473 \mathrm{~K})$.

The present study was aimed at understanding the effect of increasing $\mathrm{Al}$ and $\mathrm{Mn}$ in Mg-based alloys on their microstructure and tensile properties. Fracture surfaces of selected tensile bars were examined to arrive at a better understanding of alloy failure mechanism.

\section{Experimental Procedure}

It should be mentioned here that throughout the text all elements are given in wt\%. Table 1 shows the chemical composition of the experimental alloys used in the present study. Pure $\mathrm{Mg}, \mathrm{Al}$, and $\mathrm{Zn}$ were used as base metals. Manganese was added in the form of Al-25 wt\% Mn master alloy. The $\mathrm{Mg}$ alloy was held at $720^{\circ} \mathrm{C}$ to prepare the alloys shown in Table 2. Melting was carried out in an Fe crucible of $25 \mathrm{~kg}$ capacity. The crucible was placed in an electrical 
TABLE 1: Chemical composition of the Mg-Al-Zn alloys used in the present study (wt\%).

\begin{tabular}{lcccc}
\hline Alloy code & $\mathrm{Mg} \%$ & $\mathrm{Al} \%$ & $\mathrm{Zn} \%$ & $\mathrm{Mn} \%$ \\
\hline A & 95.56 & 4.00 & 0.44 & 0.13 \\
B & 92.22 & 7.00 & 0.78 & 0.20 \\
C & 90.00 & 9.00 & 1.00 & 0.26 \\
D & 87.78 & 11.00 & 1.22 & 0.27 \\
E & 84.44 & 14.00 & 1.56 & 0.27 \\
\hline
\end{tabular}

TABLE 2: Average grain size of the phases in the alloys used in the present study.

\begin{tabular}{lc}
\hline Alloy code & Grain size $(\mu \mathrm{m})$ \\
\hline A & 105 \\
B & 110 \\
C & 115 \\
D & 130 \\
E & 138 \\
\hline
\end{tabular}

resistance furnace. The surface of the molten alloys was protected from oxidation using a special gas (a mixture of dry air $\left(78 \% \mathrm{~N}_{2}\right.$ and $\left.22 \% \mathrm{O}_{2}\right), \mathrm{CO}_{2}$, and $\left.\mathrm{SF}_{6}\right)$.

The liquid alloy was mechanically stirred for 5 minutes at $120 \mathrm{rpm}$ prior to casting in a metallic mold preheated at $200^{\circ} \mathrm{C}$ (Figures $1(\mathrm{a})$ and $1(\mathrm{~b})$ ). The casting was mainly used for microstructural characterization as well as chemical analysis. Another set of castings was made using a standard ASTM B-108 mold (made of cast iron) to produce tensile bars (Figures $1(\mathrm{~d})(\mathrm{i})$ and $1(\mathrm{~d})(\mathrm{ii})$ ). The mold was preheated at $500^{\circ} \mathrm{C}$ whereas the molten alloy was poured at $720^{\circ} \mathrm{C}$. In both cases the solidification rate was more or less the same as inferred from measuring the alloy grain size. Figure 1(c) shows the procedure followed to measure the grain size.

Microstructures were examined by means of a Leica DM LM optical microscope. The grain-size measurements were carried out using a Clemex image analyzer in conjunction with the optical microscope. The grain size was obtained from the average of 200 measurements taken over 20 fields (10 measurements per field) at 100x magnification for each alloy sample. Phase identification was carried out using an electron probe microanalyzer (EPMA) in conjunction with energy dispersive X-ray analysis (EDX) and wavelength dispersive spectroscopic analysis (WDS) where required, integrating a combined JEOL JXA-89001 WD/ED microanalyzer operating at $20 \mathrm{KV}$ and $30 \mathrm{nA}$, where the size of the spot examined was $\sim 2 \mu \mathrm{m}$.

The tensile test bars were pulled to fracture at room temperature at a strain rate of $4 \times 10^{-4} \mathrm{~s}^{-1}$, using an MTS servohydraulic mechanical testing machine. A strain gauge extensometer (with a $50.8 \mathrm{~mm}$ range) was attached to the test bar to measure percentage elongation as the load was applied. The tensile properties of each alloy condition were represented by the average yield stress (YS) at $0.2 \%$ offset strain, ultimate tensile strength (UTS), and fracture elongation (\%El) values, which were calculated from five tested tensile bars.

The fracture surface of selected samples was examined using the Hitachi Cold FE SU-823000 SEM. Fracture surface analysis aims at investigating the nature of the fracture for selected samples and identifying the main source of cracking and fracture for these alloys. Samples for SEM examination were prepared from the tensile-tested specimens by sectioning them $1 \mathrm{~cm}$ immediately below the fracture surface and mounting them carefully for subsequent fracture surface examination.

\section{Results and Discussion}

The distribution of the Mg-phase particles in the present alloys is shown in Figure 2. When $\mathrm{Al}$ is about $4 \%$, only traces of $\mathrm{Mn}-\mathrm{Al}$ phase $[11,12]$ can be observed, in the A alloy (Figure 2(a)). Figures 2(b)-2(d) reveal the gradual increase in the volume fraction of the $\mathrm{Mg}-\mathrm{Al}-\mathrm{Zn}$ phase particles, mainly $\operatorname{Mg}_{17}(\mathrm{Al}, \mathrm{Zn})_{12}$ [13-15], with the increase in the amount of added $\mathrm{Al}$, Figure 2(e) clearly showing the eutectic morphology of the phase. It is evident from Figure 3 that the morphology of the Mg-Al- $\mathrm{Zn}$ phase has been changed from spongy-like into a more or less flat surface when the increase in the $\mathrm{Al}$ content exceeds $9 \mathrm{wt} \%$. Figure 4 displays the fraction of the $\mathrm{Mg}$ phase as a function of $\mathrm{Al}$ concentration. It is evident from Figure 4 that the surface fraction of the $\mathrm{Mg}$-Al- $\mathrm{Zn}$ phase increased from about 0.3 to $11 \mathrm{wt} \%$ with the increase in the $\mathrm{Al}$ concentration from 4 to $14 \mathrm{wt} \%$. Also, the standard deviation is less than $7 \%$ indicating the uniform distribution of this phase throughout the matrix regardless of the aluminum content. Figure 5 illustrates the distribution of $\mathrm{Al}, \mathrm{Zn}$, and $\mathrm{Mn}$ in the $\mathrm{C}$ and $\mathrm{E}$ alloys. As can be seen, over the aluminum range of 7 to $14 \mathrm{wt} \%$, both $\mathrm{Al}$ and $\mathrm{Zn}$ are distributed uniformly within the $\mathrm{Mg}-\mathrm{Al}-\mathrm{Zn}$ phase particles. The Mn-Al phase appears in the form of scattered particles away from the $\mathrm{Mg}-\mathrm{Al}-\mathrm{Zn}$ phase particles (see white circled areas). Table 2 shows the grain size has not been significantly affected by the increase in the aluminum content.

The stress-strain curves obtained from the five studied alloys are shown in Figure 6(a). It is evident that the alloy with low aluminum content, that is, $4 \%$ (the A alloy), achieved the maximum ductility (approximately 16\%) which is very close to pure $\mathrm{Mg}$ [16]. With the increase in the concentration of $\mathrm{Al}$ and the corresponding increase in the amount of Mg-phase particles, both YS and UTS parameters revealed degradation reaching minimum at $11 \mathrm{wt} \% \mathrm{Al}$. In contrast, \% elongation increased more or less linearly with the increase in the added amount of $\mathrm{Al}[17]$.

Figure 6(b) summarizes the results presented in Figure 6(a). The yield strength of the A alloy is the lowest among all alloys (approximately $120 \mathrm{MPa}$ ), whereas those of B-D are almost similar, in the range of $135-138 \mathrm{MPa}$. The E alloy exhibited somewhat higher YS, about $153 \mathrm{MPa}$ (with a standard deviation of about 1.6 MPa), solid line in Figure 6(b). 


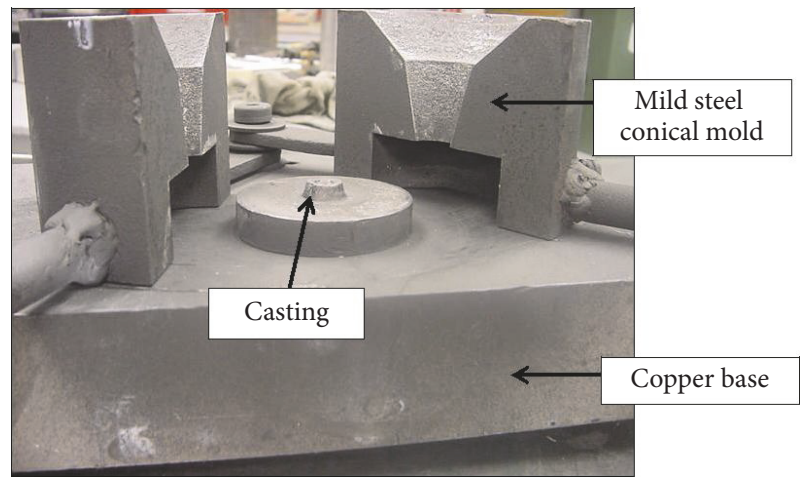

(a) Mild steel mold with copper base and casting for microstructure examination

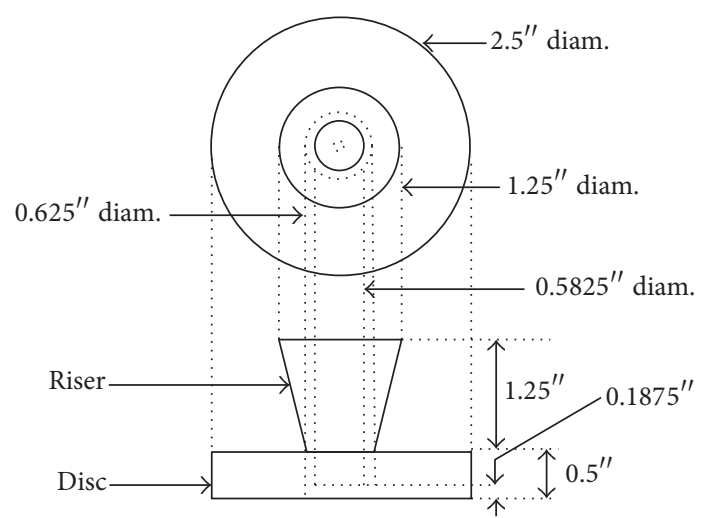

(b) Schematic diagram of the mold used (dimensions are in inches)

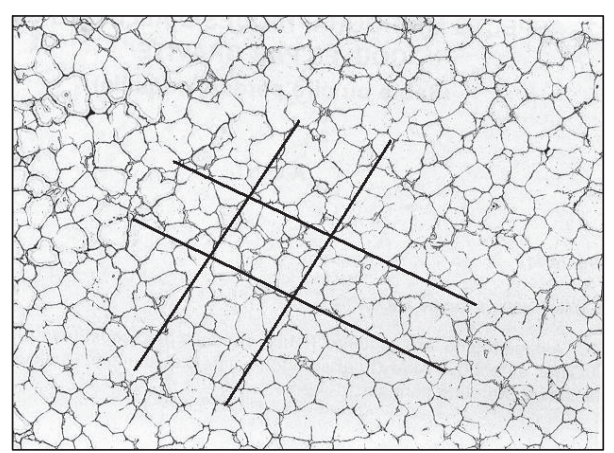

(c) Line intercept method used for the measurement of grain size

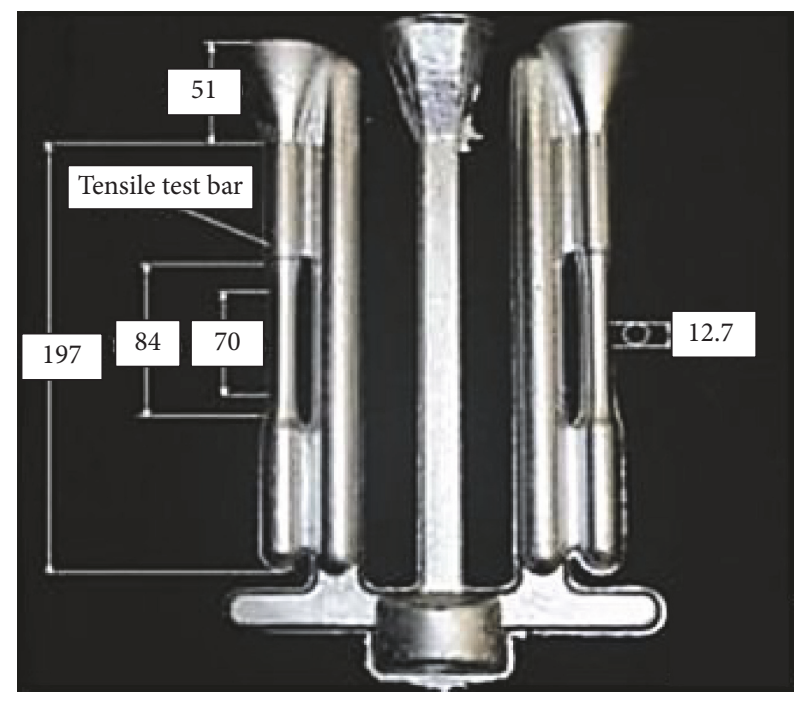

(i)

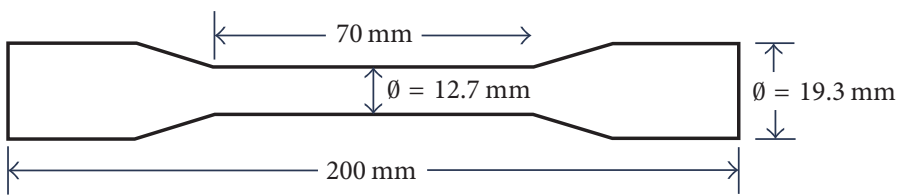

(ii)

(d) (i) Tensile test bar casting obtained from ASTM B-108 permanent mold and (ii) schematic of the tensile test bar (all dimensions are in mm)

Figure 1 


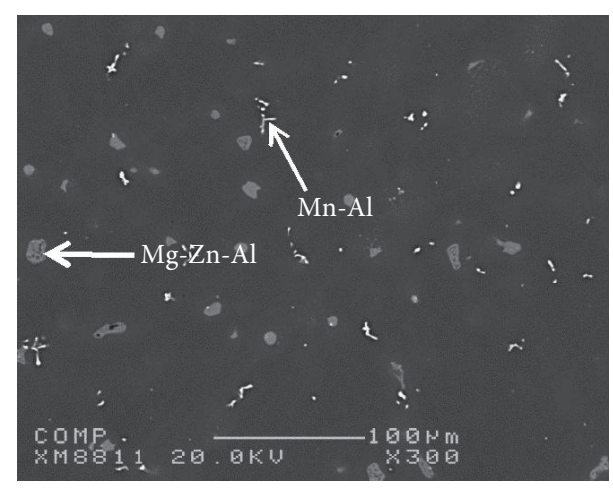

(a)

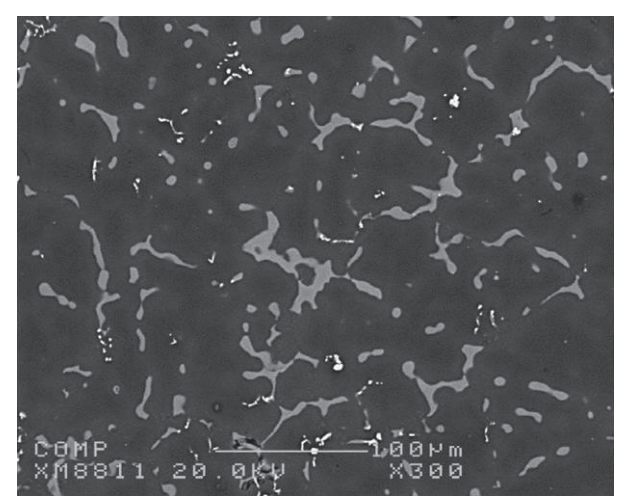

(c)

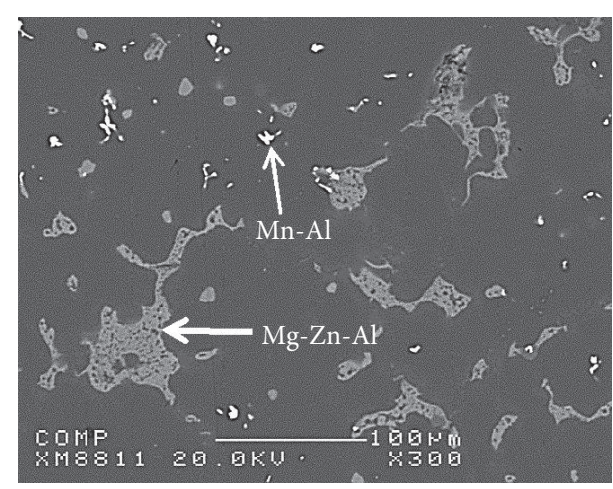

(b)

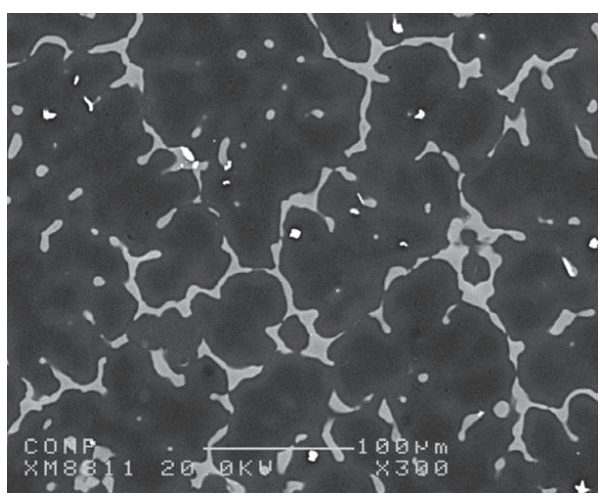

(d)

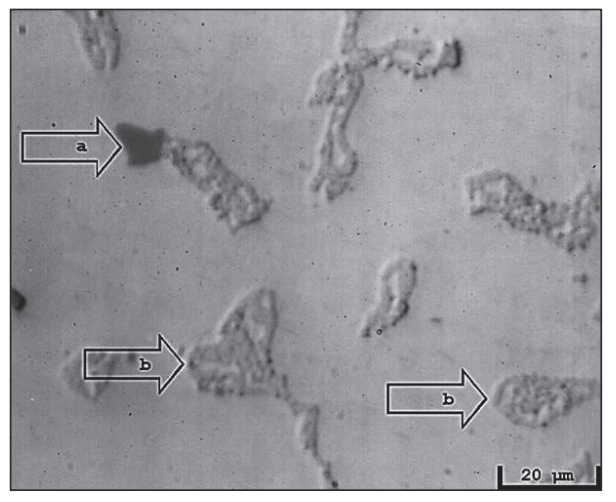

(e) Optical microstructure of the C alloy showing (a) $\mathrm{Al}-\mathrm{Mn}$ phase and (b) $\mathrm{Mg}_{17}(\mathrm{Al}, \mathrm{Zn})_{12}$ phase; note its eutectic morphology

Figure 2: Backscattered electron images showing the size and distribution of the Mg-Al-Zn phase in: (a) A alloy, 4 wt\% Al; (b) C alloy, 9 wt\% $\mathrm{Al}$; (c) D alloy, $11 \mathrm{wt} \% \mathrm{Al}$; (d) E alloy, $14 \mathrm{wt} \% \mathrm{Al}$. Note: white particles are Mn-Al phase and gray particles are Mg-Al-Zn phase.

The variation in the alloy ultimate tensile strength (UTS) is not, however, proportional to the amount of the added Al. The UTS reaches its maximum level at $7 \% \mathrm{Al}$ (B alloy) followed by gradual decrease with the increase in the $\mathrm{Al}$ percentage up to $11 \%$, broken line \#2. The $\% \mathrm{El}$ revealed a marked decrease with the increase in aluminum content compared to the other two tensile parameters. The decrease in $\%$ El exhibited an exponential trend as shown by the broken line \#3 in Figure 6(b). The present data are comparable with those obtained by Guangyin et al. [13] for the SJTU-HM1 (a rare earth-containing Mg-5\%Al-0.9\%Zn-0.71\%Si-0.4\%Sb$0.2 \% \mathrm{RE}$ alloy) and AE42 alloys investigated by them and which showed superior ductility to that of the AZ91 alloy tested at room temperature. It should be mentioned here that neither $\mathrm{Sb}$ nor rare earth metals were added to the present alloys.

The quality of aluminum alloy castings may be expressed numerically. Drouzy et al. [18] first proposed the following equation:

$$
\mathrm{Q}=a \mathrm{UTS}+d \log (\% \mathrm{El} \text { at failure })
$$




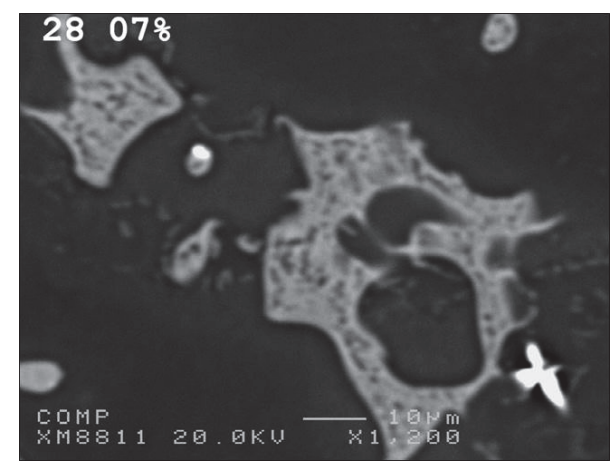

(a)

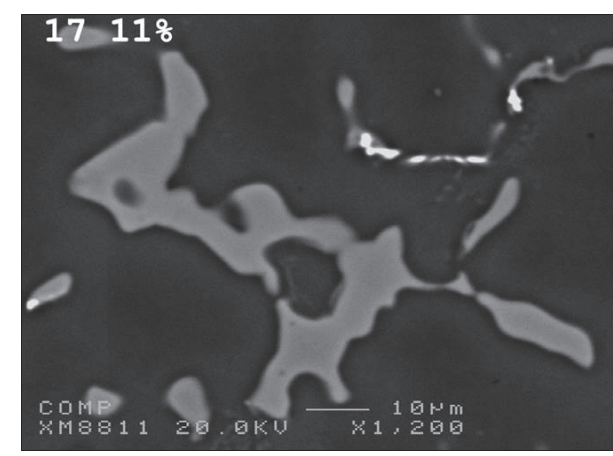

(c)

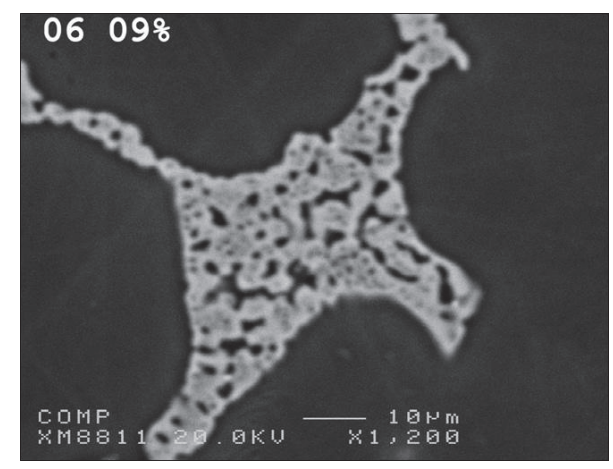

(b)

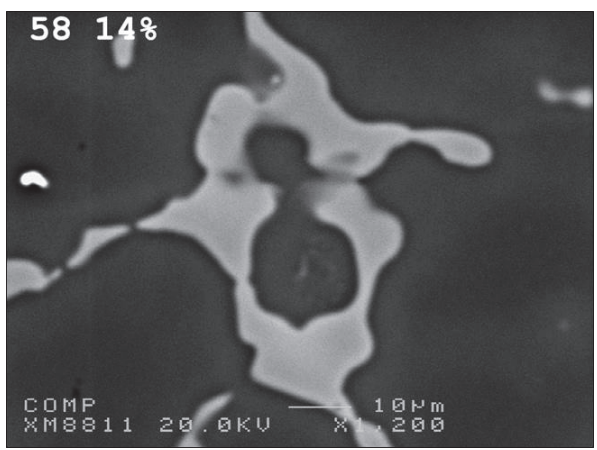

(d)

FIGURE 3: High magnification backscattered electron images of (a) 7\% Al, (b) $9 \% \mathrm{Al}$, (c) 11\% Al, and (d) $14 \% \mathrm{Al}$.

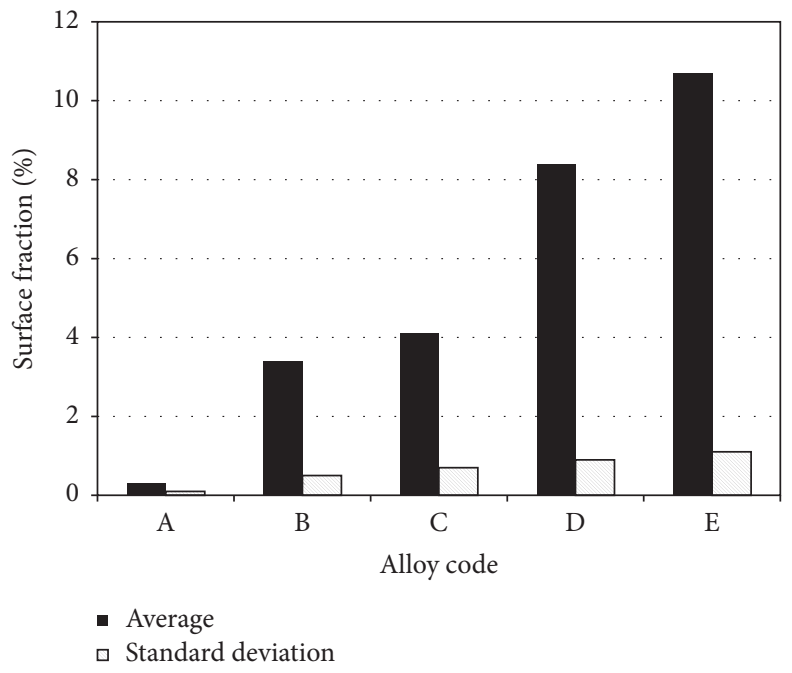

FIgURE 4: Surface fraction of the Mg-Al-Zn phase in the present alloys based on 20 fields/alloy at 100x.

where $Q$ is the quality index in $\mathrm{MPa}$, UTS refers to the ultimate tensile strength in $\mathrm{MPa}, \% \mathrm{El}$ is the percentage elongation to fracture, and $d$ is a constant of $150 \mathrm{MPa}$ for $\mathrm{Al}-$ $7 \% \mathrm{Si}-0.4 \% \mathrm{Mg}$ alloys. Figure 6(c) illustrates the variation in $Q$-values as a function of the added aluminum revealing a negative relationship between $Q$ and percentage of the added Al up to $11 \%$.
Figure 7 shows the fracture surface of the A alloy with large dimples (marked 1 in Figure $7(\mathrm{a})$ ) caused by coalescence of microporosity due to the alloy high ductility along with secondary cracks (marked 1 in Figure 7(b)). Some scattered particles of $\mathrm{Mn}-\mathrm{Al}$ phase can also be seen in Figure 7(b), marked 2. These features are comparable with those obtained from pure $\mathrm{Mg}$. With the decrease in the alloy ductility caused 

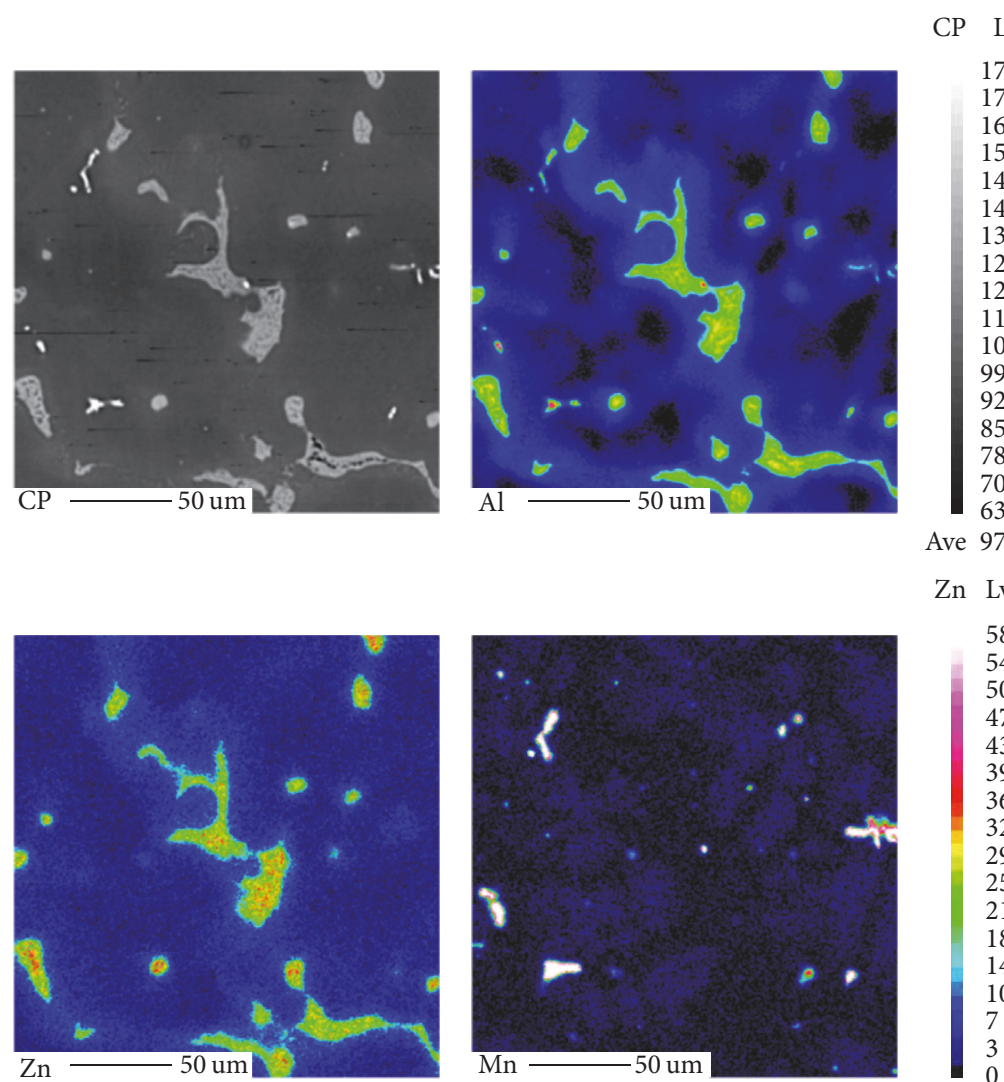

(a)
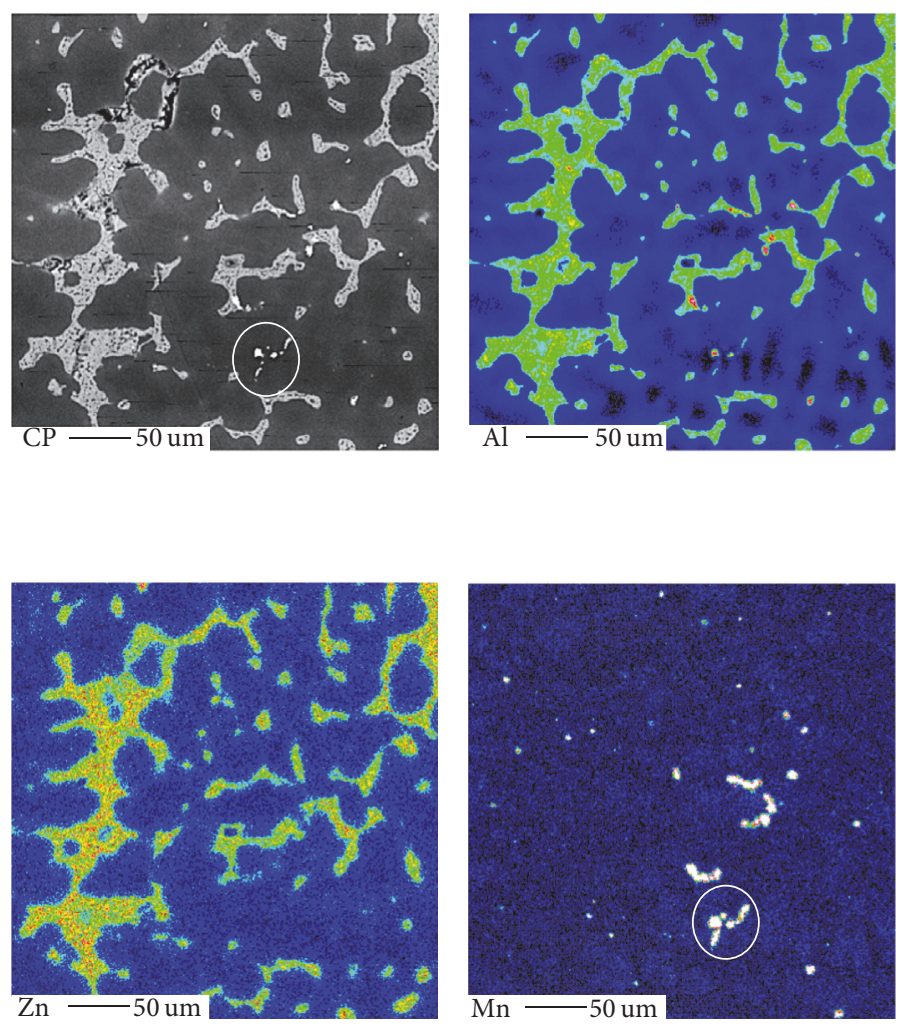

(b)

CP$$
\begin{aligned}
& 1848 \\
& 1777 \\
& 1705 \\
& 1633 \\
& 1561 \\
& 1490 \\
& 1418 \\
& 1346 \\
& 1275 \\
& 1203 \\
& 1131 \\
& 1059 \\
& 988 \\
& 916 \\
& 844 \\
& 772 \\
& 701
\end{aligned}
$$

Ave 973

$\mathrm{Zn} \mathrm{Lv}$

48
45
42
39
36
33
30
27
24
21
18
15
12
9
6
3
0

Ave 7
Ave 971

$\mathrm{Zn} \mathrm{Lv}$

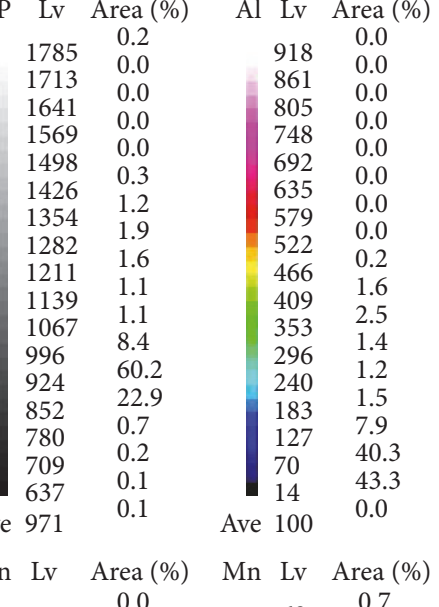

58
54
50
47
43
39
36
32
29
25
21
18
14
10
7
3
0

Ave 6

$\begin{array}{rl}68 & 0.7 \\ 64 & 0.0 \\ 60 & 0.0 \\ 55 & 0.0 \\ 51 & 0.1 \\ 47 & 0.1 \\ 43 & 0.1 \\ 38 & 0.1 \\ 34 & 0.1 \\ 30 & 0.1 \\ 25 & 0.1 \\ 21 & 0.1 \\ 17 & 0.2 \\ 12 & 0.3 \\ 8 & 0.6 \\ 4 & 9.4 \\ 0 & 88.1 \\ \text { Ave } & 0.0\end{array}$

Al Lv Area (\%)

Area (\%)

$\begin{array}{ll}1109 & 0.0 \\ 1040 & 0.0 \\ 972 & 0.0 \\ 903 & 0.0 \\ 835 & 0.0 \\ 766 & 0.0 \\ 698 & 0.0 \\ 629 & 0.0 \\ 561 & 0.0 \\ 492 & 0.9 \\ 424 & 6.2 \\ 355 & 5.8 \\ 287 & 3.6 \\ 218 & 2.4 \\ 150 & 5.0 \\ 81 & 49.4 \\ 13 & 26.4 \\ \text { Ave } 153 & 0.0\end{array}$

0.1
0.0
0.0
0.0
0.0
0.0
0.1
0.8
3.8
4.9
3.2
2.6
3.7
46.5
32.7
0.7
0.2
0.4

Area (\%)

0.0
0.0
0.0
0.0
0.1
0.2
0.6
1.4
2.5
3.4
3.8
3.5
3.7
6.9
20.8
38.1
14.8
0.0

0.0
Mn Lv Area (\%)

$\begin{array}{rl}39 & 0.6 \\ 37 & 0.0 \\ 34 & 0.0 \\ 32 & 0.0 \\ 29 & 0.0 \\ 27 & 0.0 \\ 24 & 0.1 \\ 22 & 0.0 \\ 19 & 0.1 \\ 17 & 0.1 \\ 14 & 0.1 \\ 12 & 0.1 \\ 9 & 0.2 \\ 7 & 0.3 \\ 4 & 4.8 \\ 2 & 24.1 \\ 0 & 69.5 \\ 2 & 0.0\end{array}$

Figure 5: Continued. 

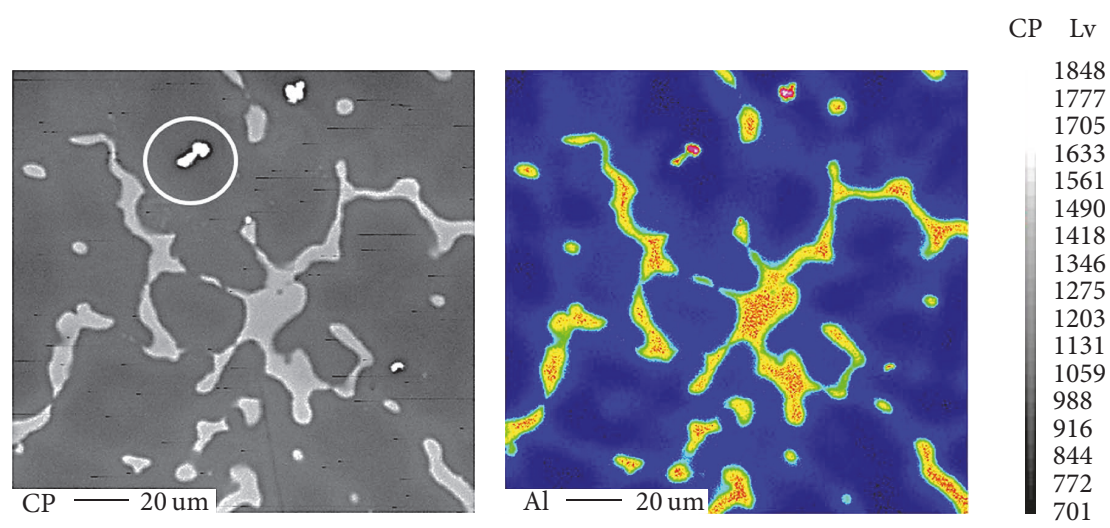

Area (\%)
0.2
0.0
0.0
0.0
0.1
1.7
4.7
3.3
1.2
1.0
1.1
2.1
26.2
50.7
7.2
0.3
0.1
0.1

$\begin{array}{ccc}\text { Al Lv } & \text { Area (\%) } \\ 960 & 0.0\end{array}$

$\begin{array}{ll}960 & 0.0 \\ 900 & 0.0\end{array}$

$\begin{array}{ll}900 & 0.0 \\ 840 & 0.0\end{array}$

$\begin{array}{ll}840 & 0.0 \\ 780 & 0.0\end{array}$

$\begin{array}{ll}720 & 0.0 \\ 660 & 0.0\end{array}$

$\begin{array}{ll}660 & 0.0 \\ 600 & 0.0\end{array}$

$\begin{array}{ll}600 & 1.7 \\ 540 & \end{array}$

$481-4.0$

$\begin{array}{ll}421 & 2.5 \\ 361 & 1.9\end{array}$

361

$\begin{array}{ll}301 & 1.8 \\ 241 & 1.9\end{array}$

$\begin{array}{ll}241 & 2.7 \\ 181 & 12.3\end{array}$

$\begin{array}{ll}181 & 12.3 \\ 121 & 50.0\end{array}$

$\begin{array}{ll}121 & 50.0 \\ 61 & 21.1\end{array}$
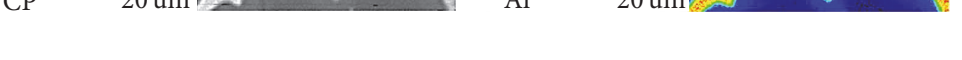

Ave 1028

Ave 139
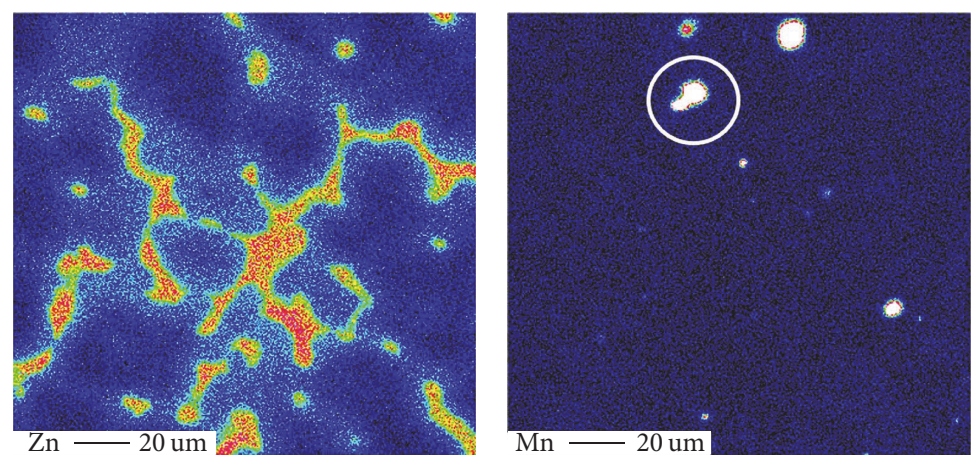

$\mathrm{Zn}$ Lv
68
63
59
55
51
46
42
38
34
29
25
21
17
12
8
4
0

Ave 11

\begin{tabular}{|c|c|c|c|}
\hline Area (\%) & $\mathrm{Mn}$ & $\mathrm{Lv}$ & Area (\%) \\
\hline 0.0 & & 55 & 0.6 \\
\hline 0.0 & & 55 & 0.0 \\
\hline 0.0 & & $\begin{array}{l}51 \\
48\end{array}$ & 0.0 \\
\hline 0.0 & & 48 & 0.0 \\
\hline 0.2 & & 44 & 0.0 \\
\hline 0.5 & & 41 & 0.0 \\
\hline 1.1 & & 38 & 0.0 \\
\hline 1.7 & & 34 & 0.0 \\
\hline 2.8 & & 31 & 0.0 \\
\hline 2.3 & & 27 & 0.0 \\
\hline 2.1 & & 24 & 0.1 \\
\hline 2.1 & & 20 & 0.1 \\
\hline 4.1 & & 1) & 0.1 \\
\hline 9.3 & & 13 & 0.1 \\
\hline 22.5 & & 10 & 0.7 \\
\hline 34.8 & & 3 & 12.0 \\
\hline 16.4 & & 0 & 86.1 \\
\hline 0.0 & Av & 3 & 0.0 \\
\hline
\end{tabular}

(c)

FIGURE 5: X-ray electron images showing elements distribution in (a) B alloy, 7\% Al; (b) C alloy, 9 wt\% Al; and (c) E alloy, 14 wt\% Al. The side bars indicate the intensity of each element. $\mathrm{CP}=$ backscattered image.

by the addition of $\mathrm{Al}$, the fracture surface of $\mathrm{B}$ alloy shown in Figure 8(a) displayed a mixture of fine dimples, marked 1 corresponding to the precipitation of $\mathrm{Mg}-\mathrm{Zn}-\mathrm{Al}$ phase particles, together with large flat fracture areas corresponding to the Mg matrix, marked 2. Figure 8(b) shows the presence of both types of intermetallics, that is, $\mathrm{Mg}-\mathrm{Zn}$-Al (marked 1) and $\mathrm{Mn}-\mathrm{Al}$ (marked 2).

The fracture surface of $\mathrm{C}$ alloy is shown in Figure 9(a) revealing the presence of particle cleavage covering most of the fracture surface. It should be mentioned here that the $\mathrm{C}$ alloy (9 wt $\% \mathrm{Al}$ ) exhibits only about $5.4 \%$ elongation (Figure 6(a)). Considering such a brittle alloy, it is expected that the crack would propagate very fast across the entire crosssection along the grain boundaries (intergranular fracture) as illustrated in Figure 9(b). The transition from transgranular (ductile alloys) to intergranular type becomes more evident with marked decrease in the alloy ductility as presented in Figures 9-11.

\section{Conclusions}

Based on the results obtained from this study, the following conclusions could be drawn:
(1) Alloys containing a low aluminum content, less than $4 \%$, are characterized by a low volume fraction of $\mathrm{Mg}$ $\mathrm{Al}-\mathrm{Zn}$ phase particles (less than $0.3 \%$ ). In this case, both $\mathrm{Al}$ and $\mathrm{Zn}$ are in solid solution in the $\mathrm{Mg}$ matrix.

(2) Precipitation of the Mg-Al-Zn phase in the form of eutectic particles heterogeneously distributed in the $\mathrm{Mg}$ matrix is observed when the $\mathrm{Al}$ content is about $7 \%$.

(3) At higher $\mathrm{Al}$ content (9\%), the $\mathrm{Mg}-\mathrm{Al}-\mathrm{Zn}$ phase particles are precipitated homogeneously throughout the matrix maintaining the same morphology as in Figure 2.

(4) When the aluminum content exceeds $11 \%$, the $\mathrm{Mg}$-Al$\mathrm{Zn}$ phase precipitates in the form of massive particles with smooth surfaces and high density.

(5) Addition of $\mathrm{Al}$ and $\mathrm{Zn}$ to $\mathrm{Mg}$ alloys leads to a marked decrease in the alloy ductility.

(6) The mechanical property plots show that $9 \mathrm{wt} . \% \mathrm{Al}$ alloys have a good balance of strength and ductility corresponding to the widely used AZ91D alloy.

(7) The fracture mechanism of the present alloys was found to be directly related to the amount of added 

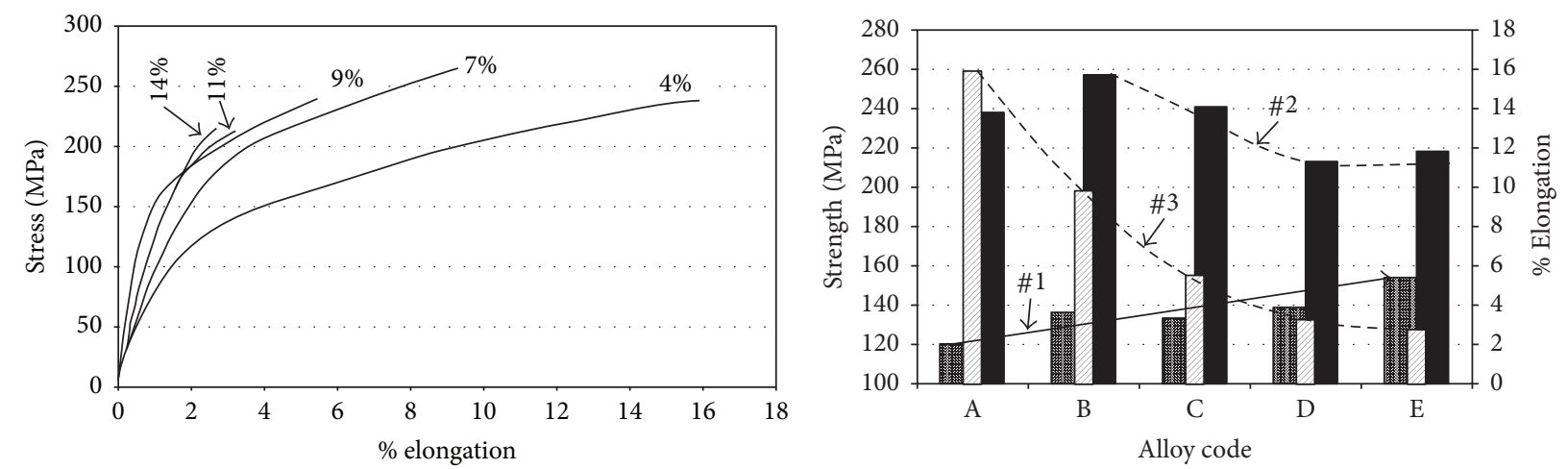

$$
\begin{aligned}
& \text { YS (MPa) } \\
& \text { - UTS (MPA) } \\
& \square \text { \% }
\end{aligned}
$$

(a) Typical stress-strain curves obtained from the alloys used in the present study as a function of percentage of $\mathrm{Al}$

(b) Variation in the tensile properties as a function of the added $\mathrm{Al}$ content. Each value is an average of 10 tensile bars

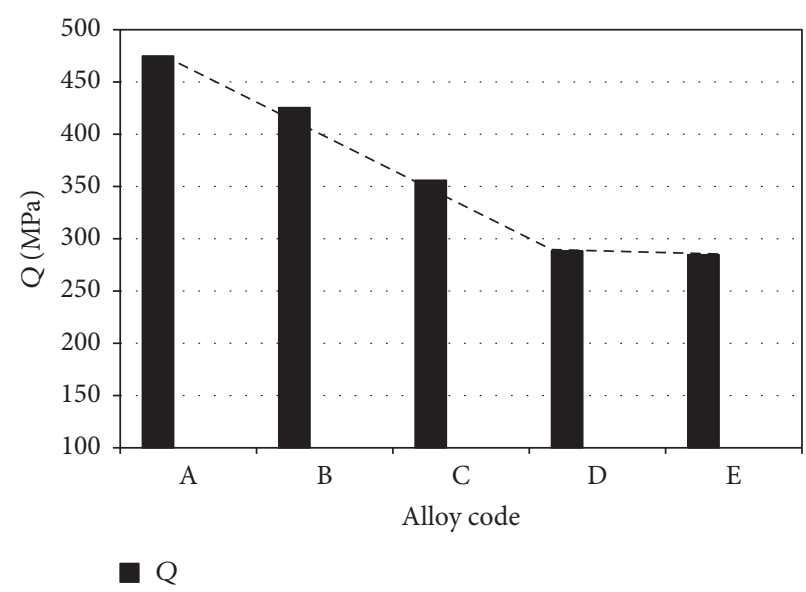

(c) Variation in Q-values as a function of $\% A l$; see Table 1

Figure 6

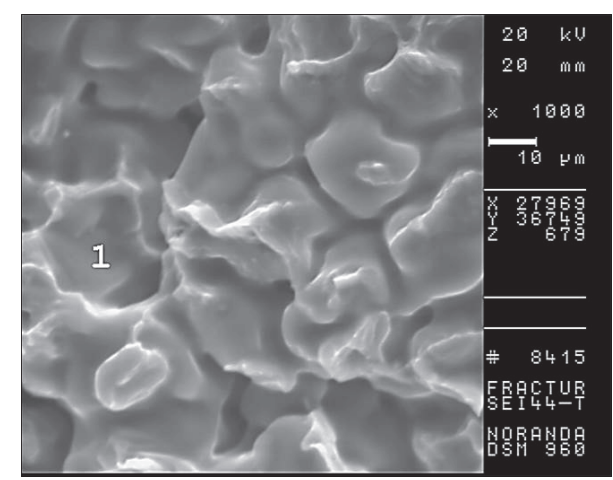

(a)

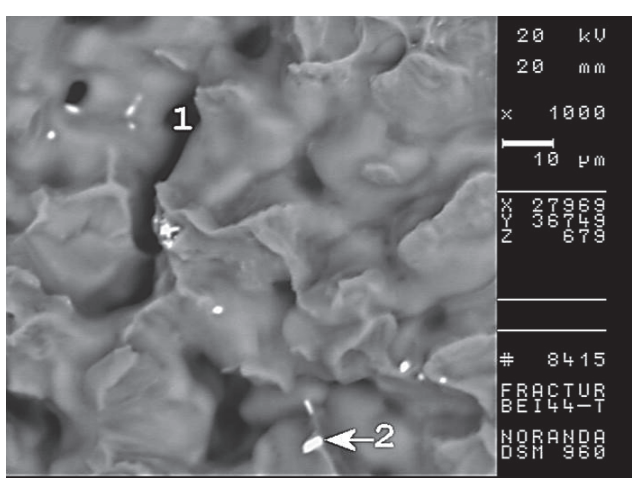

(b)

FIgURE 7: (a) Secondary electron image of the A alloy, $4 \mathrm{wt} \% \mathrm{Al}$; (b) backscattered electron image of (a). 


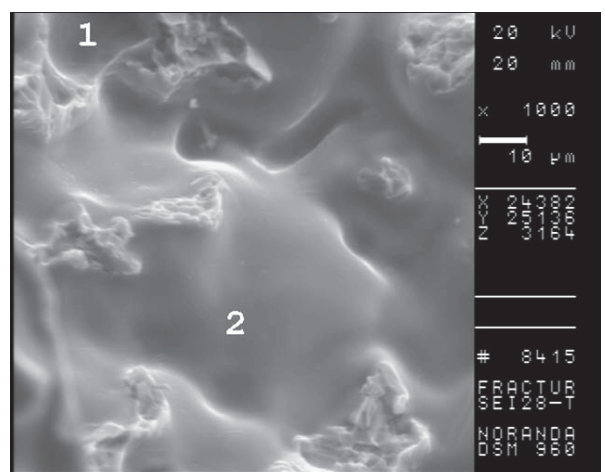

(a)

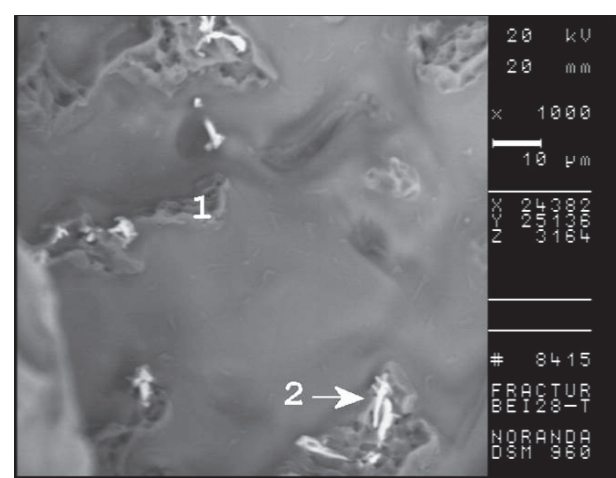

(b)

Figure 8: (a) Secondary electron image of the B alloy, 7\% Al; (b) backscattered electron image of (a).

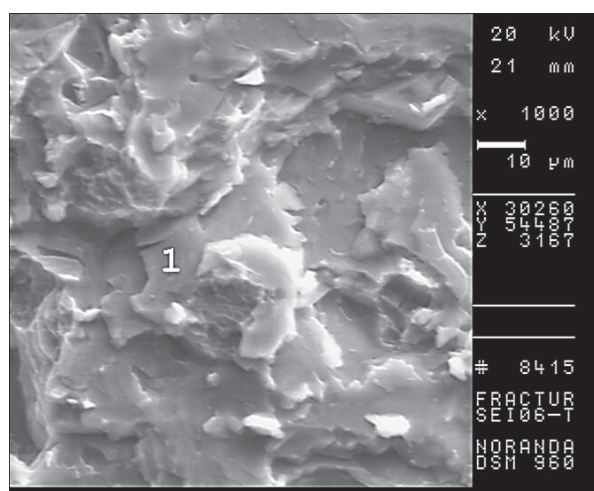

(a)

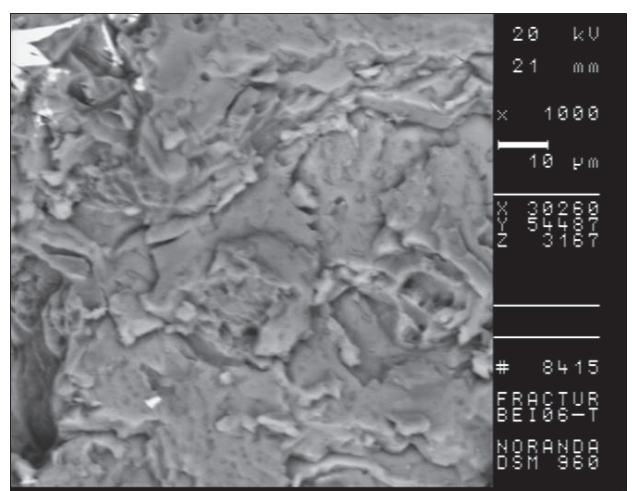

(b)

Figure 9: (a) Secondary electron image of the C alloy, 9 wt\% Al; (b) backscattered electron image of (a).

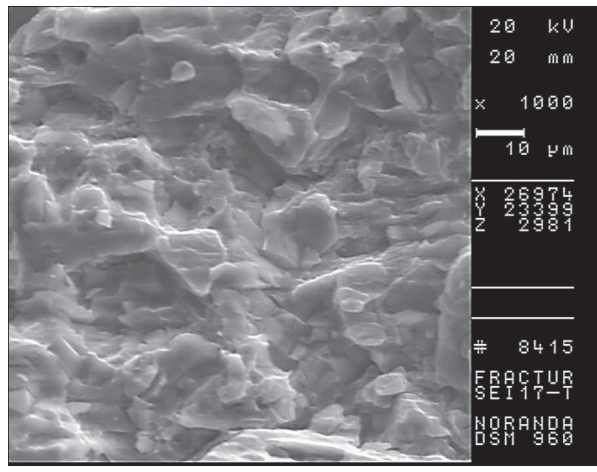

(a)

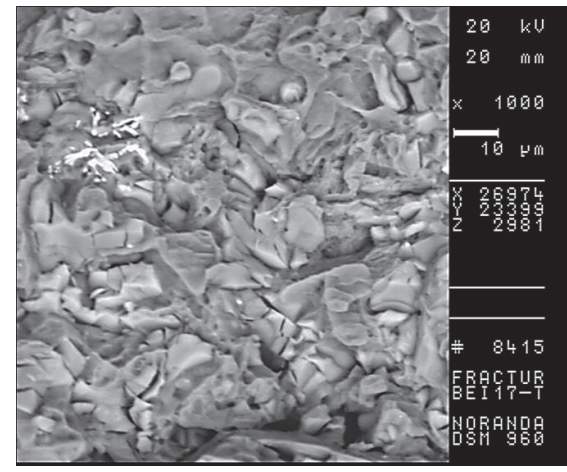

(b)

Figure 10: (a) Secondary electron image of the $\mathrm{D}$ alloy, $11 \mathrm{wt} \% \mathrm{Al}$; (b) backscattered electron image of (a).

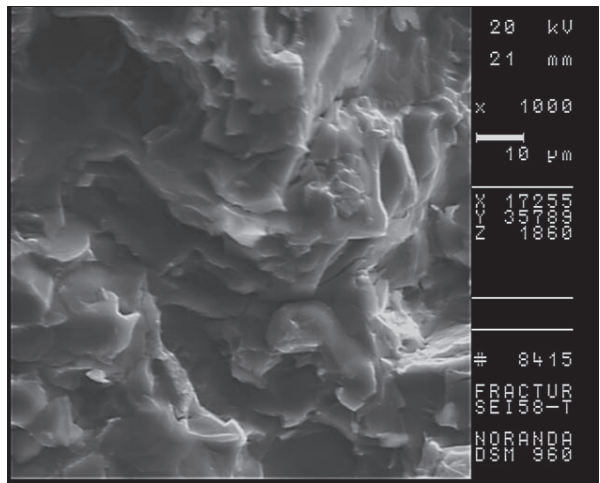

(a)

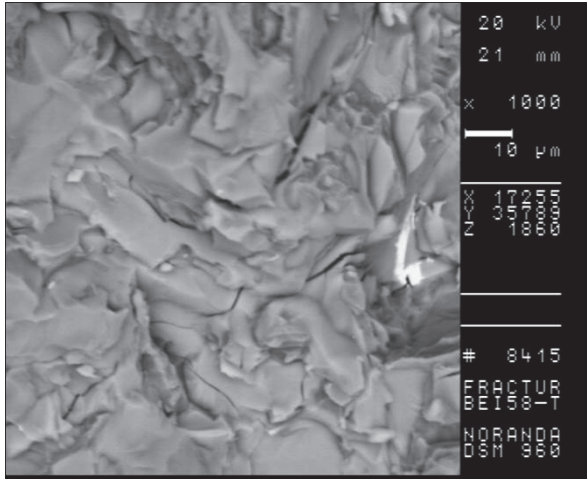

(b)

Figure 11: (a) Secondary electron image of the E alloy, $14 \mathrm{wt} \% \mathrm{Al}$; (b) backscattered electron image of (a). 
aluminum. The transition from ductile fracture to a brittle one takes place when the $\mathrm{Al}$ concentration exceeds $9 \%$.

\section{Conflicts of Interest}

The authors declare that they have no conflicts of interest.

\section{Acknowledgments}

The authors would like to thank Dr. Carlton Fuerst, Chief Scientist, General Motors Canada, for suggesting the present research topic. Thanks are also due to Amal Samuel for enhancing the images used in this article.

\section{References}

[1] J. T. Black and R. A. Kohser, DeGarmo's Materials and Processes in Manufacturing, 11th edition, 2012.

[2] A. Lindemann, J. Schmidt, M. Todte, and T. Zeuner, "Thermal analytical investigations of the magnesium alloys AM60 and AZ91 including the melting range," Thermochimica Acta, vol. 382, no. 1-2, pp. 269-275, 2002.

[3] S. Sankaranarayanan, S. Jayalakshmi, and M. Gupta, "Effect of individual and combined addition of micro/nano-sized metallic elements on the microstructure and mechanical properties of pure Mg," Materials and Design, vol. 37, pp. 274-284, 2012.

[4] D. H. StJohn, M. Qian, M. A. Easton, P. Cao, and Z. Hildebrand, "Grain refinement of magnesium alloys," Metallurgical and Materials Transactions A, vol. 36, no. 7, pp. 1669-1679, 2005.

[5] D. H. StJohn, A. K. Dahle, T. Abbott, M. D. Nave, and D. Qian, in Magnesium Technology 2003, San Diego, CA, H. I. Kaplan, Ed., pp. 95-100, TMS, Warrendale, PA, USA, 2003.

[6] K. Neh, M. Ullmann, and R. Kawalla, "Effect of grain refining additives on microstructure and mechanical properties of the commercial available magnesium alloys AZ31 and AM50," in Proceedings of the Materials Today, vol. 2, 1, pp. S219-S224, 2015.

[7] J. Hirsch and T. Al-Samman, "Superior light metals by texture engineering: optimized aluminum and magnesium alloys for automotive applications," Acta Materialia, vol. 61, no. 3, pp. 818843,2013

[8] E. Essadiqi, M. T. Shehata, A. Javaid et al., Alloying and Process Design of Mg Sheet, CANMET Materials, Ottawa, Canada, 2011.

[9] A. Yamashita, Z. Horita, and T. G. Langdon, "Improving the mechanical properties of magnesium and a magnesium alloy through severe plastic deformation," Materials Science and Engineering: A, vol. 300, no. 1-2, pp. 142-147, 2001.

[10] K. Kubota, M. Mabuchi, and K. Higashi, "Processing and mechanical properties of fine-grained magnesium alloys," Journal of Materials Science, vol. 34, no. 10, pp. 2255-2262, 1999.

[11] P. Cao, M. Qian, and D. H. Stjohn, "Effect of manganese on grain refinement of Mg-Al based alloys," Scripta Materialia, vol. 54, no. 11, pp. 1853-1858, 2006.

[12] Y. Liu, G. Huang, Y. Sun et al., "Effect of Mn and Fe on the formation of $\mathrm{Fe}$ - and $\mathrm{Mn}$-rich intermetallics in Al-5Mg-Mn alloys solidified under near-rapid cooling," Materials, vol. 9, no. 2, article no. 88, 2016.

[13] Y. Guangyin, L. Manping, D. Wenjiang, and A. Inoue, "Mechanical properties and microstructure of $\mathrm{Mg}-\mathrm{Al}-\mathrm{Zn}$-Si-base alloy," Materials Transactions, vol. 44, no. 4, pp. 458-462, 2003.
[14] A. Bag and W. Zhou, "Tensile and fatigue behavior of AZ91D magnesium alloy," Journal of Materials Science Letters, vol. 20, no. 5, pp. 457-459, 2001.

[15] A. Shukla and A. D. Pelton, "Thermodynamic assessment of the Al-Mn and Mg-Al-Mn systems," Journal of Phase Equilibria and Diffusion, vol. 30, no. 1, pp. 28-39, 2009.

[16] H.-F. Sun, C.-J. Li, Y. Xie, and W.-B. Fang, "Microstructures and mechanical properties of pure magnesium bars by high ratio extrusion and its subsequent annealing treatment," Transactions of Nonferrous Metals Society of China (English Edition), vol. 22, no. 2, pp. s445-s449, 2012.

[17] D.-H. Li, M.-L. Hu, H.-B. Wang, and W.-A. Zhao, "Low temperature mechanical property of AZ91D magnesium alloy fabricated by solid recycling process from recycled scraps," Transactions of Nonferrous Metals Society of China (English Edition), vol. 21, no. 6, pp. 1234-1240, 2011.

[18] M. Drouzy, S. Jacob, and M. Richard, "Interpretation of tensile results by means of quality index and probable yield strength," AFS International Cast Metals Journal, vol. 5, no. 2, pp. 43-50, 1980. 

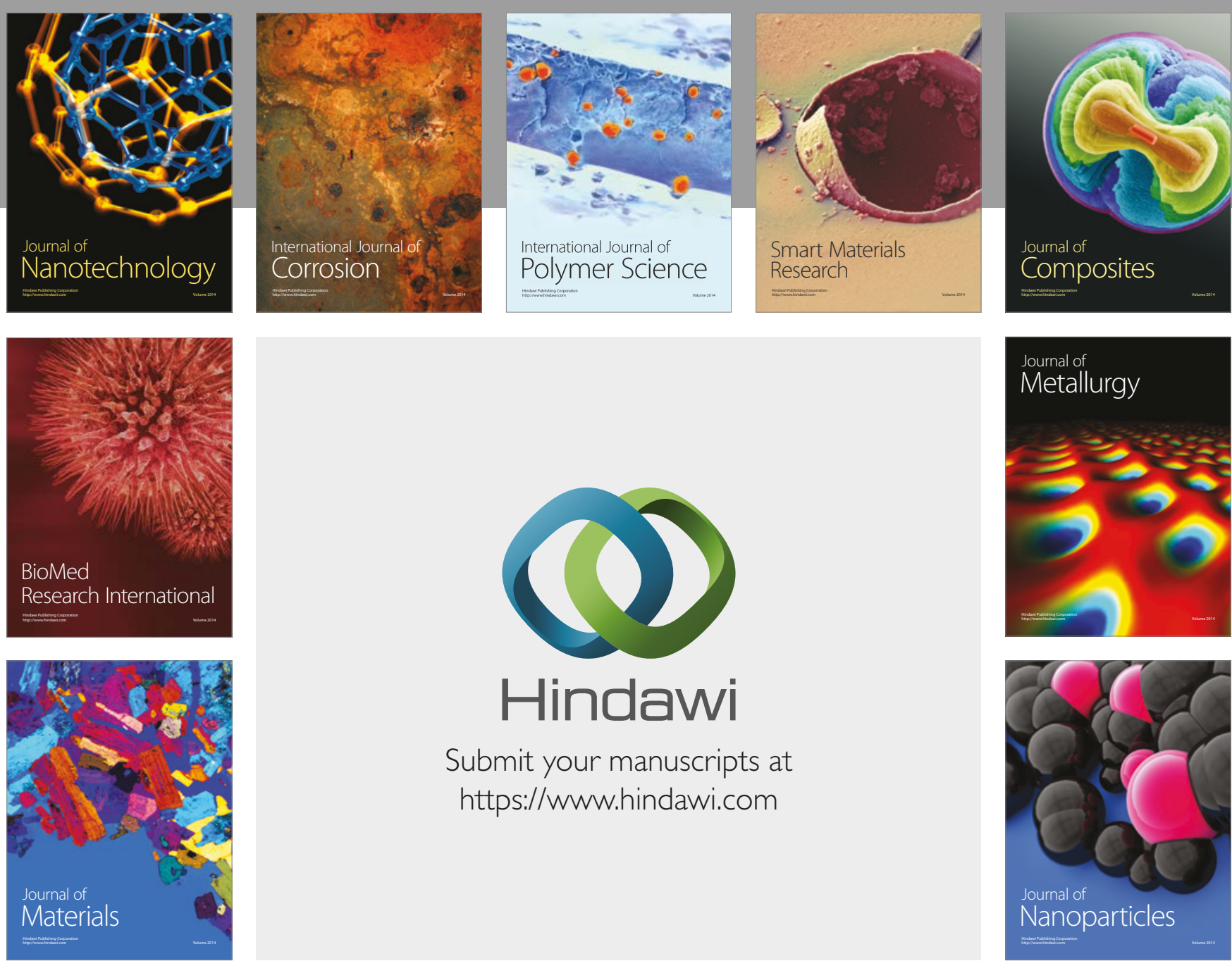

\section{Hindawi}

Submit your manuscripts at

https://www.hindawi.com
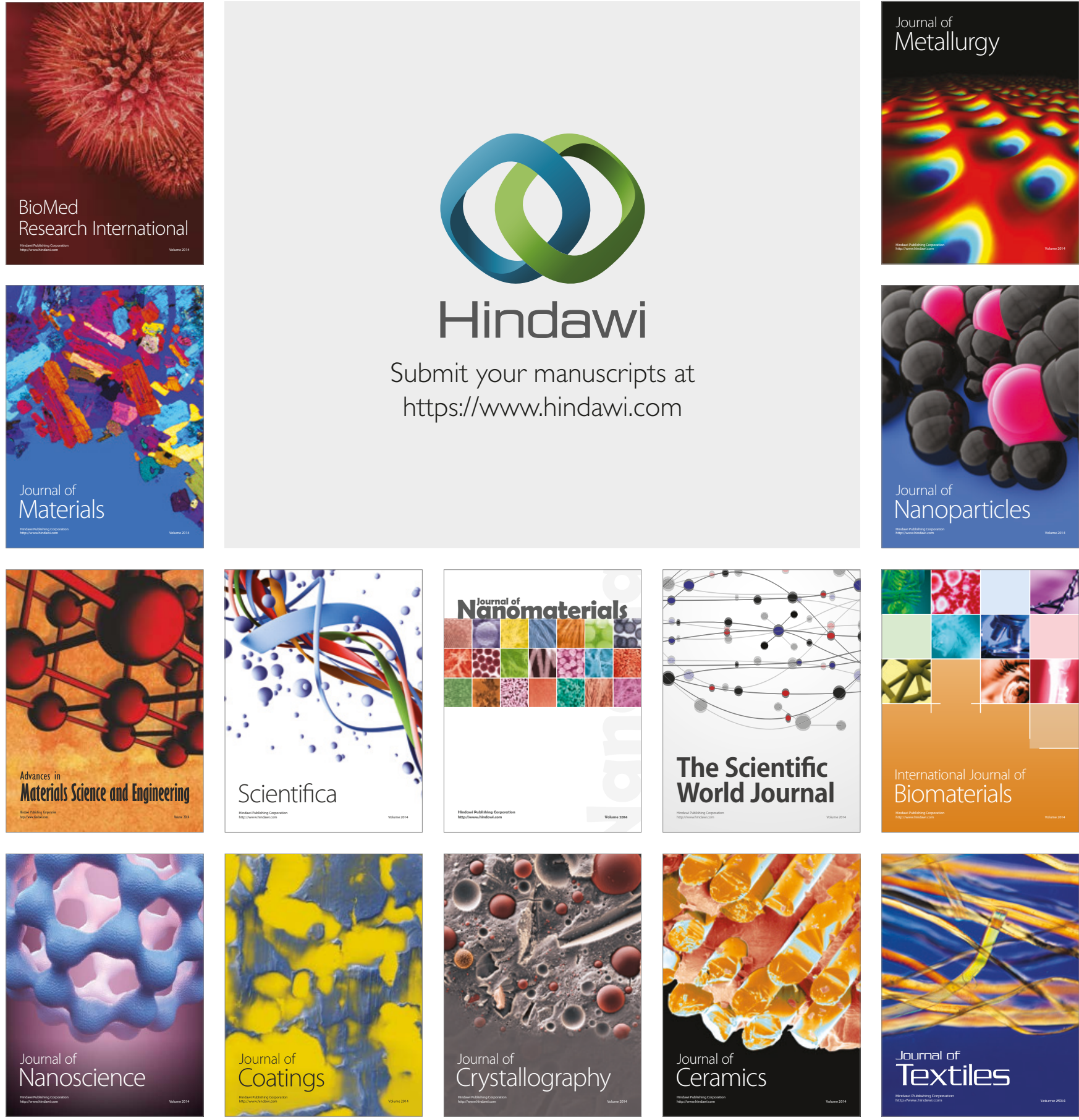

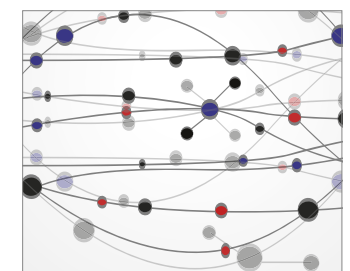

The Scientific World Journal
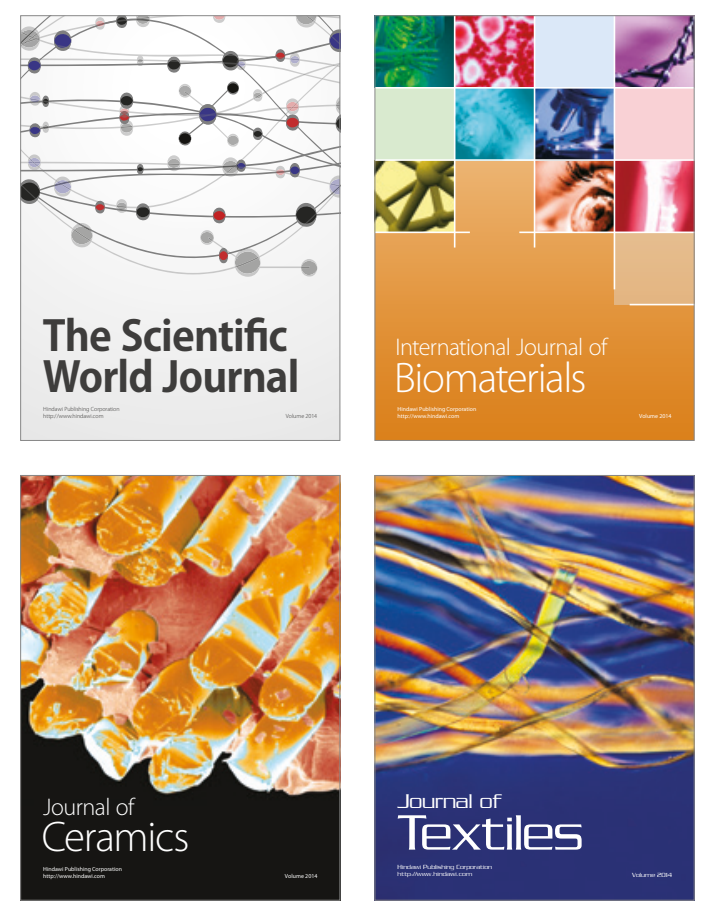